\title{
Amicus Curiae: Origin, Worldwide Experience and Suggestions for East European Countries
}

\author{
IRYNA IZAROVA* \\ BARTOSZ SZOLC-NARTOWSKI** \\ Anastasila Kovtun***
}

\begin{abstract}
This article describes the meaning of amicus curiae according to modern legislation and doctrine, as well as its origin from Roman law and English law. One part of the article is devoted to the current legal position of international institutions regarding amicus curiae and its place in different legal systems worldwide. Furthermore, the last part of the article related to the analysis of the new amicus curiae concept in Ukraine legislation, combined with the new principles of judicial case management and cooperation of the judge and parties in civil procedure. The article concludes with some thoughts about the need and viability of its implementation in the civil law countries using examples of current reforms of Civil Procedure in Ukraine, and other states of Eastern Europe.
\end{abstract}

Keywords: East European Law, Civil Procedure, Civil Litigation, Parties, Amicus Curiae

\section{INTRODUCTION}

The concept of amicus curiae is almost unknown in modern legislation and doctrine in Eastern Europe, in particular in post-socialist countries. However, this is a traditional concept for common law countries, in particular, the United States of America, where it was borrowed from the English, and also, Roman law, which requires further explanation. The European Court of Human Rights and other international judicial institutions also accept amicus briefs. Recently, during the on-going reforms of judiciary and litigation the interest for amicus curiae is growing in the civil law countries in Eastern Europe, giving it more weight and relevance for studying.

What is it and for what purpose is it involved in court proceedings? The goal of the paper is to study the origins and identify modern approaches to understanding amicus curiae in the civil process, as well as to find the answer to the question of the need and viability of its implementation in the civil law countries, in particular in Ukraine and other East European countries.

\section{THE ROMAN ORIGINS OF THE AMICUS CURIAE}

\subsection{Preface}

There are authors ${ }^{1}$ who seek the origins of the amicus curiae in Roman law. It is valid to question the very sense of asking about the Roman beginnings of amicus curiae. What would be gained from the answer, be it positive or negative? One reason to have this

* Iryna Izarova: Professor, Faculty of Law, Taras Shevchenko National University of Kyiv, irina. izarova@gmail.com.

** Bartosz Szolc-Nartowski: Assistant professor, Roman Law Department, University of Gdańsk, bszolcnartowski@gmail.com.

*** Anastasiia Kovtun: Legal consultant, Crowe UAE, anastasiia.kovtun@crowe.ae.

1 The list of authors and a description of how they refer to Roman sources is presented in the section 2.2. below. 
question answered is that it is safer to know the experience of past times. The point is not just to investigate the history of a given solution but also to expound the reasons justifying its sense and purpose while investigating and understanding a particular issue and placing it within an appropriate framework. After all, humans have not changed that much, and thus, it is a good idea to draw on the rich store of Roman legal thought. Roman solutions could provide an insight into whether a given legal problem was noticed; how it was dealt with and how and why the approach to it changed. Roman law was and continues to be a repository of combined legal wisdom, the product of collaboration and consensus rather than the effect of arbitrary commands handed down by authoritarian legislators. ${ }^{2}$

The Latin term amicus curiae is no proof of the Roman origins of the institution itself. The Latin language in Europe was part of a cultural heritage handed down by the Romans, and its importance started to decline only in the last two centuries. ${ }^{3}$ However, it certainly remains the language of the scholarly community, including but not limited to lawyers. The use of Latin terms gives the speaker an air of intellectual superiority. After all, it is the language of scholarship. Some of its vocabularies express concepts, for which a native term would be difficult to find. Undoubtedly, the legal term amicus curiae does not ring a bell to a non-lawyer. For lawyers of different nationalities, however, it is an entirely understandable concept, even though its scope in practice may involve slightly different meanings.

That is why amicus curiae should not be considered as a fixed concept, whose meaning has been set in stone forever by a legal dogma. Otherwise, the question of historical experience becomes meaningless. Therefore, in the quest for the origins of the amicus curiae, it would be well advised to avoid the pitfalls of nominalism. In our opinion, it is not very sensible to inquire whether the arrangement whereby a non-governmental organisation acting as amicus curiae appears before the European Court of Human Rights had its counterpart in Roman law. However, if amicus curiae is recognized as an entity, whose entire task is to present the court with opinions, impart knowledge that the court does not have, or provide guidance on points of law or their possible interpretation, it can be concluded that the purpose of this practice is to enable the court to comprehensively examine all the relevant facts of the case, while also taking into account the possible consequences, including social ones, of a judicial decision in the future. As such, it is one of many tools to achieve this purpose.

Latin, the lawyer's pet subject, has contributed two judicial commandments: iura novit curia $^{4}$ (the court knows the law) and vanae voces populi non sunt audiaendae ${ }^{5}$ (the hollow

2 Longchamps de Berier ( 2017) 175.

3 Sondel (2005) 9.

${ }^{4}$ A post-Roman dictum, echoing perhaps the reactions of judges who have lost their patience with the lengthy deliberations of legal counsels: Venite ad factum, curia novit ius, Vinnius (1747) 123. Another version reads: da mihi factum, dabo tibi ius. As for the practical complications of the significance and application of the maxim from a comparative viewpoint, see Cavallini (2017) link 1.

${ }^{5}$ C. 9.4 .12 (Impp. Diocletianus et Maximianus): Decurionum filii non debent bestiis subici. Cumque a populo exclamatum est, eterum [imperatores] dixerunt: Vanae voces populi non sunt audiendae; nec enim vocibus eorum credi opertet, quando qui obnoxium crimine absolvi aut innocentem condemnari desideraverint. - 'The sons of Decurions should not be exposed to wild beasts. And if the mob should clamour for this, the Emperors respond: the hollow and vain voices of the mob should not be heeded. They should not obey, either when demanding the release of a convict or when clamouring for an innocent person to be condemned.' When commenting on this rule, the medieval gloss writer Accursius went so far as to criticize Pilate for bowing to the demands of the mob in condemning Jesus - Pilatus male fecit, qui ad populi clamorem Christum condemnavit. 
and vain voices of the mob should not be heeded). Separated from their original context, these commandments continue to form part of the judicial culture. The first could mean that the parties do not have to provide evidence as to the applicable law, because the court must know the legal grounds for its rulings. The second sentence may sound perhaps somewhat inappropriate in modern times; it allows the judge to rule without regard to the pressure of public opinion or political factors. Two basic issues emerge in connection with the role of the amicus curiae, i.e. the autonomy and independence of the court. These could be expressed in the form of two simple questions. Is it proper for the court to request a third party to present a legal opinion on the case? Is it possible that this might harm the authority of the state judiciary? Is an opinion a mere show of arguments, particularly those which the court might be unfamiliar with, or does it affect judicial independence?

\subsection{Quoting Problems}

The claims about the Roman origins of amicus curiae are variously invoked, usually by quoting authors' views rather than by direct reference to the original Roman legal/literary sources. Dorota Pyć and Paulina Zajadło-Węglarz ${ }^{6}$ quote the opinion of Paul M. Collins Jr. as evidence for the institution being derived from Roman law. ${ }^{7}$ P.M. Collins Jr. in turn, quotes the findings of several authors: Frank M. Covey, ${ }^{8}$ Jr., Fowler V. Harper and Edwin D. Etherington, ${ }^{9}$ Samuel Krislov. ${ }^{10}$ At the same time, F. M. Covey believes that the origins of the amicus curiae are unclear. He also rejected the view found in the literature, which derives the contemporary practice of the amicus curiae from the Roman consilium, which he claims to have been exercised by an officer of the Roman court appointed by the judge to advise him on points on which he was in doubt. Firstly, Covey believes that the consilium could not operate on its initiative but only at the judge's request and, secondly, that Roman law entitled the consilium to make arguments against the defendant in criminal proceedings, which is impossible nowadays. ${ }^{11}$ It is remarkable that F.V. Harper and E.D. Etherington arbitrarily, without any further explanation, accept the amicus curiae as originating from Roman law. ${ }^{12}$

Interestingly, F. M. Covey and S. Krislov base their view of the Roman origins of the amicus curiae on a dictionary, or rather a concise encyclopedia, by John Bouvier, whose first edition appeared in 1839. The quoted version here is the eighth edition of that work, reviewed for the third time by Francis Rawle. This work of reference states that the judge (iudex) under Roman law called on a lawyer for assistance with legal advice, see the quote below:

The judex, especially if there were but one, assumed some lawyers to assist him with their counsel, (sibi advocavit, ut in concilio adessent). ${ }^{13}$

${ }^{6}$ Cf. Pyć, Zajadło-Węglarz (2014) 5.

7 Collins (2008) 38.

8 Covey (1959) 33-34.

9 Harper and Etherington (1953) 1176.

10 Krislov (1963) 694.

11 Covey (1959) 34.

12 Harper and Etherington (1953) 1176.

13 Bouvier, s.v. amicus curiae, (1914) 188. 
There are also non-legal texts that point to primary sources, e.g., fragments of M.T. Cicero's speech in defence of Publius Quintus (Pro Publio Quinctio); a collection of tales by Aulus Gellius entitled 'Attic Nights' (Noctes Atticae) and The Life of Emperors (De vita Cesarum) by Suetonius. ${ }^{14}$ However, the author goes only so far as to indicate the sources without trying to argue the factual points. In fact, the author only notes that the sources describe a custom whereby the judge would seek advice. That custom is supposed to have been incorporated into English law. The language and the content of the relevant entry in J. Bouvier's reference work make it seem quite probable that he based his information on a popular work by Alexander Adam entitled Roman Antiquities, which appeared for the first time in 1791. On an Account of the Manners and Customs of the Romans was later supplemented and reviewed by J. Boyd and L. L. Da Ponte. ${ }^{15}$ In his description of Roman litigation, A. Adam (subsection: Manner of Conducting a Trial) relies, as he does with all his treatment of Roman law, mainly on non-legal sources, such as the works by Cicero, Aulus Gellius and Suetonius, quoted later by J. Bouvier.

Steven Kochevar writes on the authority of S. Krislov as 'Amicus briefs are an ancient legal instrument, originating in Roman law and appearing early in the common law tradition'. ${ }^{16}$ Elsewhere, he follows Krislov again and Ernest Angell in writing ${ }^{17}$ 'although amicus briefs have been a common law phenomenon for the last several centuries, the procedure originated in Roman law'. However, E. Angell's article on Amicus Curiae only has the sentence that the device was known in Roman law but provides no sources, literary or otherwise. Instead, the text itself refers to interested readers to the already known article by S. Krislov. Michael K. Lowman postulates the Roman origins of the amicus curiae and, to lend weight to his claim, cites the opinions of various authors, most of whom were listed above. $^{18}$

However, attempts have been made recently to clarify the Roman tradition of this institution. S. Chandra Mochan maintains it is correct to derive amicus curiae from Roman origins and this is supported by the Roman practice of appointing the consilium or a group of independent advisors to assist officials. She associates this practice with the role played by the amici in all aspects of Roman life. ${ }^{19}$ This is contested by Luigi Crema who rejects the thesis about the Roman roots of the amicus curiae. He argues that, save for a terminological similarity, there are no other commonalities which would resemble the contemporary practice of amicus curiae. ${ }^{20}$ Providing advice has nothing to do with this institution as it is known today. In Rome, the advice was called for, while nowadays the amicus submits a brief or presents arguments on its initiative. In Rome, such advice was confidential, while the amicus brief was open. Another difference is that amici curiae do not file their representations at the discovery stage but present their briefs or make arguments orally before the court in session.

14 Cic. Quin. 2, Gell. 14, 2; Suet., Tib. 33.

15 Adam (1842) 165-66.

16 Kochevar (2012-2013) 1653.

17 Angell (1967) 1017.

18 Lowman (1992), 1244, footnote 7.

19 Mohan (2010) 352-74.

20 Crema (2012) link 12. 
The authors only incidentally refer to the question of the origins of the amicus curiae. This is understandable, as they aimed to analyze contemporary legal problems. However, it is clear that the Roman beginnings of the amicus curiae are, in some respects, an unclear issue which therefore needs better research and documentary evidence. At this point, it appears necessary to mention some information relevant in the context of Roman litigation.

\subsection{Roman Litigation. Structural Differences}

Roman law developed three kinds of civil litigation: legis actiones, formulary and cognition. ${ }^{21}$ There were considerable differences between legis actiones, formulary and cognitio procedures. In the first two instances, the litigation has two stages. The first stage proceeded before a state authority having jurisdiction, initially, a praetor and later also the provincial governor. It focused mainly on points of law: admissibility of the dispute, determination of the competent court to hear the proceedings in the second stage, preparing an agenda for the trial, which specified the claim and contained instruction for the judge to conduct the proceedings and pass judgment.

The second stage concentrated on points of fact and was divided into evidence proceedings and the award of judgment. The presiding judge was either appointed by the parties or by an official, after consultation with the parties. The second stage, designated as iudicare and iudicatum, i.e. adjudicating upon the case, distinguished clearly between magistrate jurisdiction and the activity of the judge (iudex).

The magistrates with jurisdiction were not required to be experts in the law. The council (consilium) composed of jurists was available to assist on points of law. Its opinion was not binding, but it carried great weight in practice. In formulary litigation, jurists sat in on the proceedings to give advice and possibly help to set down in writing the orders of the magistrates. ${ }^{22}$

The judges were also not legal professionals. ${ }^{23}$ The proceedings, which they oversaw, were virtually concerned only with points of evidence and adjudication for or against the defendant. Nonetheless, the stage of proceedings which was overseen by the judge allowed certain points of evidence to be raised, e.g., in connection with determining the rank of particular items of evidence and their evaluation. The legal issues related to the growing inclusion of judges (arbiters) in matters related to the division of landed property or inheritance and most importantly, to the consequences of good faith in the case of bonae fidei iudicia ${ }^{24}$ must not be forgotten. Defenses and replies could also be the object of the legal assessment.

${ }^{21}$ For a broader treatment of Roman civil litigation, cf. Kaser (1996); Lately, an interesting survey of Roman procedure, citing general reference works and shorter or introductory works has been undertaken by Metzger (2015) 272-98.

${ }^{22}$ See Schulz (1968) 103, 111, 210-211. Cf. also Cic., Top., 17, 65; D. 31.29 pr. (Celsus trigesimo sexto digestorum).

23 Apart from few exceptions, cf. Schulz (1968) 104. The lack of legal expertise of Roman judges (imperitia iuris) was remedied by the possibility of having them selected by the parties. As a result, a dispute could be resolved by a person with experience and practical knowledge of a given field, see Gagliardi (2007) 215-17.

24 This was a kind of procedure in which the judge had the widest extent of discretionary powers. This was because the judge was not restricted by procedural formulae and the defences that they provided for. The formula empowered the judge to adjudicate against the defendant what he 
A judge, who is passing an unjust sentence through his fault, would be liable to reimburse the aggrieved party in the amount determined by the court (iudex qui litem suam fecit). The sentence did not have to contain a statement of reasons.

The cognitio procedure was conducted before a state-appointed judge, usually an imperial official. ${ }^{25}$ This was a far cry from the formulary procedure, in which the judge was a private person and fully independent. The division into two stages was absent; the procedure was conducted entirely before an official or a state-appointed judge, about whose choice the parties, unlike in the previous case, had no say.

By the time of Emperor Hadrian, it was recommended that each official having iurisdictio was accompanied by a legal advisor. The advisors were known as adsessores, comites, consiliari and sometimes as studiosi iuris. It is believed that these advisors also enjoyed wider powers, and they were the real decision-makers in many cases. ${ }^{26}$ However, their opinions were not binding on the official or judge.

Administrative state practice gave rise to an interesting institution known as consultatio ante sententiam. In cases of doubt about a legal matter, the judge after satisfying himself as to the facts of the case could request a higher court (including especially the Emperor) in writing for clarification (consultatio, relatio, opinio, suggestio). The request contained a summary of the case. The institution operated from the reign of Trajan and developed as a result of queries submitted to the Emperor by imperial officials, mainly provincial governors. This institution, known as consultatio ante sententiam, was regulated by Constantine the Great with subsequent minor improvements in later times. ${ }^{27}$

A remarkable feature of the Roman legal system was that judiciary functions were assigned to non-lawyers. However, praetors, lay judges and later imperial officials, could take advantage of a consilium composed of legal experts.

owed the plaintiff in good faith. Quintus Mucius Scaevola, a great lawyer living at the end of the Republican period, said that adjudicating in good faith requires an excellent judge; cf. Cic., De off. 3, 17, 70. Decisions made in individual cases reflected the belief held by society corresponding to good faith in a specific legal relationship. Decisions referring to specific persons had the characteristics of generally applicable law (bonae fidei iudicio conveniens videtur). This paved the way for vendor's liability for latent product defects. For more information on the subject, cf. Cic, De off, 3, 16, 66. More on this in Voci (1994) 23-24. Even though the formula did not lay down a clear command, the judge was obliged to consider previous rulings. This is confirmed by Gaius in his discussion of the judge's duty to consider mutual set-off, cf. Gai, 4, 63. It seems that the role of jurists acting as advisors to the court was significant in the case of iudicia bonae fidei. They could present the judge with previous rulings in similar cases.

${ }^{25}$ Hearing cases was the responsibility, above all, of the emperor and officials whose titles dated back to the Republican constitution, such as consuls, praetors as well as imperial functionaries. On the other hand, these officials did not always preside in personam over the proceedings, delegating their powers to judges (iudex datus, iudex pedaneus).

${ }^{26}$ Cf. Schulz (1968) 211.

27 The judge first issued an ex officio interlocutio for consultatio. Next, the judge drafted a written consultatio containing a legal query and a summary of the case, with copies provided to the interested parties. The parties could motion the court for preces refutatoriae, in which they stated their positions with respect to relatio. The judge would then hand over consultatio, preces refutatoriae and the case file to a higher court by official channels. Under classical Roman law, the response only clarified the legal point in question and returned the case to the petitioning court, whereby the lower court was then obliged to consider the advice in its ruling. In the post-classical period, the ruling was made by the petitioned court. See more on the subject in: Litewski (1969), 227-57. 


\subsection{Advisor, Consiliarius and Amicus Iustitiae}

Focus now moves to the other fragments in the literature in support of the Roman origins of the amicus curiae. The first is found in M.T. Cicero's speech in defense of Publius Quinctius (Pro Publio Quinctio). ${ }^{28}$ In all probability, the fragment in question is the one, in which Cicero approaches the judge Gaius Aquilius and the members of the council (vosque, qui in consilio adestis) on behalf of his client Publius Quinctius ${ }^{29}$ for an injunction to put a stop to the dishonorable injustice that she claims to have afflicted his client. Similar calls to the judge and council are scattered throughout the speech. ${ }^{30}$ The judge appointed three lawyers to the consilium, to whom Cicero also appeals. They have an advisory vote, but their opinions are not binding. However, their status is official in that they appear at trial to hear the arguments presented by the parties.

On the other hand, in De vita Ceasarum, Suetonius, who lived 150 years after Cicero, describes how Tiberius was in the habit of proffering his counsel and assistance to officials hearing a case in court, ${ }^{31}$ by sitting next to or opposite them on a nearby platform. ${ }^{32}$ The Roman writer also reports on somewhat different activities of the Emperor. When rumors came to his attention of a defendant who might escape justice through wealth and influence, he would suddenly appear in court to remind the judges of the applicable laws, their sacred character and the type of offence in question. ${ }^{33}$ The Emperor can be said to be, first of all, Amicus Curiae and, secondly, the amicus iustitiae. At one time, the Emperor is a party to the discussion; at another, he reminds the judge of his responsibilities and the applicable laws.

${ }^{28}$ Cic. Quin., 2.

29 The judge Gaius Aquilius Gallus's advisors were Publius Quintilius Varus, Marcus Claudius Marcel and Lucius Lucillius Balbus, cf. Cic., Quin., 17.

${ }^{30}$ Cf. Cic., Quin., 6.

${ }^{31}$ In a public proceeding (iudicium publicum) in criminal cases. In Roman law, iudicia publica covered only certain criminal matters, cf. D. 48.1 .1 (Macer libro primo de publiciis iudicis) and Inst. 4,18 .

32 Svet., Tib. 33.: (...) magistratibus pro tribunali cognoscentibus plerumque se offerebat consiliarium assidebatque iuxtim vel exadversum in parte primori; et si quem reorum elabi gratia rumor esset, subitus aderat iudicesque aut e plano aut e quaesitoris tribunali legum et religionis et noxae, de qua cognoscerent, admonebat. According to Tacitus, Tiberius would sit at the corner of a table in order not to detract from the praetor's authority, Cf. Tac., Ann., 1, 75 - iudiciis adsidebat in cornu tribunalis, ne praetorem curuli depelleret. Multaque eo coram adversus ambitum et potentium preces constituta. Tiberius's active involvement in the proceedings is also mentioned in Cassius Dio, see Dio 57.7.6. Indeed, it is believed that all the authors relied on an earlier source, see Bablitz (2009),121-33; According to the author, the place where Tiberius was seated at trial seems to indicate his wish to appear in his traditional role as assessor without his position as Emperor interfering with judicial decisions. It would not be amiss to quote here the following observation of Bablitz (2009) 132: 'no matter how softly he walked, he was still a very big elephant in every space he entered.'

33 Svet., Tib. 33.: '(...) magistratibus pro tribunali cognoscentibus plerumque se offerebat consiliarium assidebatque iuxtim vel exadversum in parte primori; et si quem reorum elabi gratia rumor esset, subitus aderat iudicesque aut e plano aut e quaesitoris tribunali legum et religionis et noxae, de qua cognoscerent, admonebat.' 


\subsection{Rogatio in Consilium. Aulus Gellius's Testimony}

The notes, or rather a collection of tales by Aulus Gellius, entitled Noctes Atticae was written under the reign of the Antonines. ${ }^{34}$ It is the picture of intellectual life at the time but offered a large amount of valuable information on the former times. Among the trivia, anecdotes, stories and reflections filling the pages of the Noctes Atticae, there are interesting fragments on Roman law. One of these passages concerns issues related to the exercise by Aulus Gellius the office of a judge and the advice that his friends offered him. Aulus Gellius had no legal education or nor practical experience. So, after being listed as a judge, he felt obliged to start studying law. He could not train with a lawyer, because he writes that he had learnt the legal profession from lex Iulia ${ }^{35}$ the works of the lawyer Massurius Sabinus ${ }^{36}$ and other commentaries of Roman jurists. He also took advantage of works on philosophy and rhetoric. The works he had studied were of no use, however as they did not guide a judge on how should he rule in complicated cases where it was difficult to arrive at a judgment. Gellius was assigned to precisely this kind of case. He was to resolve a dispute for the repayment of a loan in a formulary proceeding. In the course of evidence proceedings, it turned out that the plaintiff failed to show any documents or witnesses to confirm that the loan had taken place. However, the plaintiff was a trustworthy person, of impeccable reputation, well-known for his honesty. The defendant, on the other hand, was of ill-repute and had a previous record of perjury and fraud. However, the defendant's position was that the case was one of loaned money, to be settled by a lay judge rather than one of a moral nature, to be adjudicated by a censor. The defendant, together with his patrons, was adamant that the plaintiff should prove traditionally, by presenting evidence or witness statements, that he had lent the money. If this could not happen, he demanded his release and also that the plaintiff should be punished for vexatious litigation. Friends (amici mei) with relevant experience as lawyers and judges were too busy with other matters and gave rushed advice that did not seem convincing to Gellius. In their opinion, he should release the defendant since the plaintiff had failed to present any evidence to support his claim. Gellius then suspended the case and contacted his friend Flavorinus, an already well-known philosopher at the time, for help in resolving the case in accordance with legal principles. Flavorinus consulted De officio iudicis, a work by Q. Aelius Tuberon, who was a lawyer in the $1^{\text {st }}$ century BCE, told Gellius several remarks relating to judicial procedure, drawing his attention to selected issues which gave rise to disputes. Concerning the case, Gellius proposed to accept the counsel (consilium) of Marcus Cato, ${ }^{37}$ who thought that where a case cannot be resolved based on documents or witnesses, the judge should consider the reputation of each of the parties at trial. If one of them was a better person (vir melior), both were equally virtuous or wicked; the defendant should win the case. However, Gellius took neither his friends' nor Flavorinus's advice. The matter was complicated as the defendant maintained that he had never taken any loan but also demanded that the plaintiff be punished for vexatious litigation, resulting in the plaintiff's infamy. Gellius, who was more concerned

${ }^{34}$ General information on the work of Aulus Gellius is presented by Zabłocki (1999) 9-17, 21. A broder discussion of the case, Zabłocki (1999) 83-106.

35 Leges Iuliae iudiciorum publicorum et privatorum 17 BC; cf. Gai. 4.104.

$361^{\text {st }}$ century $\mathrm{AD}$, a distinguished jurist, vested by Emperor Tiberius with ius respondendi; author of Libri tres iuris civilis.

37 An opinion expressed by M. Cato in his speech in defence of Lucius Turius against Gneius Gellius ( $2^{\text {nd }}$ century BC). 
about moral rather than legal misgivings, ${ }^{38}$ refuse to adjudicate the case, deciding that the case was not clear to him (rem sibi non liquere).

The fragment written by Aulus Gellius is one of the most interesting testimonies in the literature relating to the everyday practice as a lay judge. Firstly, it shows that the judge was faced with several procedural problems which he had to resolve. Obtaining advice from a lawyer, especially in the provinces, could be impossible. The only thing that remained was the 'silent sources', legal regulations and juristic commentary. The latter could also be hard to come by in practice. Practical advice was offered by 'amici', who had already practised as lay judges or lawyers, or in fact rhetoricians who appeared in court on behalf of their clients. It is interesting that Gellius asks the philosopher Flavorinus for help with the case. Flavorinus was thought to be an authority by Gellius, or at least a mine of information. However, in making his decision, Gellius remains true to his duty and stays independent.

To conclude, it worth to mention that in classical Roman law where the judge was most frequently a non-lawyer, a private person, a vir bonus, or a trustworthy man, there was demand for knowledge of the law, both substantive and procedural, and sometimes also of the interpretation of factual circumstances. However, any judgement that was passed only applied inter partes and had no impact on further judiciary practice. The judge only adjudicated based on the facts. One exception was the iudicia bona fidei.

In cognitio litigation, where all judiciary functions were exercised by the state administration, judges were merely imperial officials, but even they needed consultation. Here, however, the imperial authority was at stake, hence the practice of hiring professional lawyers and of formalized internal consultation with a higher-order authority prior to passing judgment.

\section{BRIEF REVIEW ON THE CURRENT LEGAL POSITION OF INTERNATIONAL INSTITUTIONS REGARDING AMICUS CURIAE AND ITS PLACE IN DIFFERENT LEGAL SYSTEMS WORLDWIDE}

\subsection{Amicus Curiae in Common Law System}

United States of America (USA) can unquestionably be named as the most successful platform for filing the amicus briefs as they have been part of the USA legal system since the nineteenth century. ${ }^{39}$ The Supreme Court of the United States of America has considerably helped the cause of amicus curiae with its open-door policy for amicus briefs. ${ }^{40}$ The court averaged about 13 briefs per argued case. ${ }^{41}$ There is even an opinion that amicus curiae participation is a staple of interest group activity in the USA Supreme Court. $^{42}$

It should be emphasized, that in common law the amicus briefs appeared as a type of partial expert in community interests - the role of amicus curiae in common law was as that of the disinterested bystander who offered the court important information or suggestions. ${ }^{43}$ The amicus curiae in the United States of America today is far from a casual

38 Zabłocki (1999)106.

39 Lucas (1999), also for wider historical insight.

40 Anderson (2015).

${ }^{41}$ For statistical information, see Franze and Anderson (2016).

42 Collins (2004).

43 Krislov (1963). 
bystander giving impromptu advice - it is mostly an experienced counsel representing an interest group, which may be millions in number, and participates to advance the cause of the clients rather than to assist the court as a friend. ${ }^{44}$

The role of amicus curiae in the Supreme Court of the United States of America is regulated by the Rule 37 of The Rules of the Supreme Court, which contains explicit guidelines regarding amicus curiae participation on the merits: ${ }^{45}$

amicus curiae brief that brings to the attention of the Court relevant matter not already brought to its attention by the parties may be of considerable help to the Court. Only an attorney admitted practicing before the particular Court may file it. ${ }^{46}$

Amicus briefs are expressly permitted also by Federal Rule of Appellate Procedure, in Article 29:

The United States or its officer or agency or a state may file an amicus curiae's brief without the consent of the parties or leave of the court; any other amicus curiae may file a brief only by leave of court or if the brief states that all parties have consented to its filing. ${ }^{47}$

Every country of common law jurisdiction recognizes certain practice of amicus curiae participation. In the case of Australian law, reference should be made to High Court Amendment Rules of 2004 recognizes written submissions by interveners. In Australia, as in the United States of America, the amicus which assists the court is not an original party to the proceedings, and its position is also quite different from that of an intervening party. ${ }^{48}$

One important difference between the United States of America and Australia is that in the USA the courts have a far greater acceptance of the political nature of their role. ${ }^{49}$ Furthermore, if the winning party is assisted by the contribution of an amicus, the unsuccessful party is not liable in costs to the amicus. However, the position in Australia is quite different - if an amicus contributed to an Australian case in favor of the losing party, it is likely that this party would be liable in costs to the amicus. ${ }^{50}$ Nonetheless, the legal system of Australia is going in the same 'political' direction as the USA system.

The role of an amicus in Great Britain is, to a large extent, similar to the Australian one and can be described by quoting Lord Salmon in Allen v Sir Alfred McAlpine \& Sons Ltd [1968] 2 QB 229 at p. 266 F-G:

I had always understood that the role of an amicus curiae was to help the court by expounding the law impartially, or if one of the parties were unrepresented, by advancing the legal arguments on his behalf. ${ }^{51}$

${ }^{44}$ Loretta (1984).

45 Rules of The Supreme Court of The United States, at Part Vii. Rule 37.

46 Rules of The Supreme Court of The United States, at Part Vii. Rule 37.1.

47 Federal Rule of Appellate Procedure, at Article 29.

${ }^{48}$ Loretta (1984).

49 Loretta (1984) 529.

50 Loretta (1984) 530.

51 For more information, see Allen v Sir Alfred McAlpine \& Sons Ltd [1968]. 
Objectively, Australia inherited the legal procedures on amicus curiae from England. In pre-eighteenth-century England, the amicus was a neutral lawyer physically present in the courtroom who would engage in an impromptu 'oral 'sheperdizing', the bringing up of cases not known to the judge.' 52

Now the acceptance of amicus briefs in the United Kingdom appears more alike with the fact-gathering methods of some inquisitorial civil law courts ${ }^{53}$ - courts may appoint amicus curiae to gather and submit research, amicus activity constitutes a civil law moment, in which a court can gather facts without relying on the efforts of the disputing parties before it. $^{54}$

\subsection{Amicus Curiae in Civil Law Countries}

The use of amicus briefs in common law courts and international proceedings is well documented and have been greatly discussed, so a more recent trend to have evaded through treatment about the amicus briefs in civil law courts. ${ }^{55}$

Historically, briefs by amicus curiae did not appear in civil law jurisdictions. Indeed, lately, amicus briefs rise in the European Union and in other countries that belong to the civil law countries, particularly in France, Netherland, Poland and others.

This broad development can be explained by two major trends. Firstly, various civil law jurisdictions have formally recognized amicus briefs through statutes, court decisions and rules. It is mainly the influence of general tendencies towards the globalization of procedural law. Secondly, non-governmental organizations regularly submit amicus briefs to civil law courts, even though such courts did not adopt any formal instruments to accept them. NGOs informally submit briefs to courts in virtually every region in the world, from Southeast Asia $^{56}$ to Russia. ${ }^{57}$

Nowadays, the national courts of every member state of the European Union must recognize a form of amicus involvement. At the level of pan-European legislation, some European Council Regulations recently came into force and allowed the antitrust authorities of the member states, as well as the European Commission, submit written observations to national courts on proceedings related to antitrust. ${ }^{58}$ The antitrust authorities or the Commission may also provide oral observations with court permission. ${ }^{59}$ Also, the process is expected to be vice versa, and the national courts may request amicus briefs from competition authorities or the Commission in antitrust proceedings.

It was repeatedly noted that the introduction of amicus curiae in Europe was influenced by its British concept. However, the national courts in Poland have used amicus briefs since the 1990s. The Trybunal Konstytucyjny formally recognized amicus briefs in 1997 with lower courts now also accept them. ${ }^{60}$

52 Lucas (1999).

53 Supreme Court of United Kingdom: The Supreme Court Rules (2009), on Rule 35.

54 Langbein (1985).

55 Koshevar (2013).

56 For more information, see Prefel S.A. v. Jae Ik Choi (filed July 23, 2002).

57 Prefel S.A. v. Jae Ik Choi (filed July 23, 2002).

58 Koshevar (2013).

59 Commission observations to National Courts [Amicus curiae observations, Article 15(3)].

60 Bernatt (2008) and Bodnar (2010). 
French courts have also already used it to some extent in the past century, and it is slowly becoming now a part of the French procedural system. ${ }^{61}$ The Paris Court of Appeal resorted to the concept of amicus curiae for the first time in 1988 when requested to rule on an issue relating to the application of rules governing the profession of lawyer. ${ }^{62}$ The Court asked the President of the Paris Bar, precisely as amicus curiae to

provide, in the presence of all interested parties, all the observations that may enlighten the court in its process of solving the dispute. ${ }^{63}$

In 1991, the Court accepted its first amicus brief and in 2010, the rules of the Conseil d'Etat, France's highest administrative court, were amended to allow amicus briefs formally. ${ }^{64}$

On the contrary, the phenomenon of amicus curiae was never familiar in Dutch law, but due to EU law has become part of it. This absence was due to another basic principle of Dutch civil procedure is that third parties cannot meddle in a civil procedure. For this reason, the new provision had to be implemented - the new article 44(a) of Dutch Code of Civil Procedure contains the provision that the Administrative Council of the Commission exercises its competence, they act as amicus curiae, a position that has very much in common with the Dutch Public Prosecution Department. ${ }^{65}$

\subsection{International Courts' Legal Position about Amicus Curiae}

The participation of amicus curiae in litigation is a practice which is increasingly being entrenched in common law and civil law jurisdictions but also domestic and international legal tribunals. ${ }^{66}$ This development of the use of amicus briefs in international proceedings has been well documented and has been well discussed in recent decades. ${ }^{67}$ Due to the way the practice has evolved in different legal systems, it has become

versatile, and the amicus now fulfils a wide range of diverse and important functions. ${ }^{68}$

The European Court of Human Rights ${ }^{69}$ accepts amicus briefs. Amicus participation is also allowed in many international investment arbitrations. ${ }^{70}$ For example, Chapter 11 tribunals under the North American Free Trade Agreement may accept amicus briefs. ${ }^{71}$

${ }^{61}$ Coslin \& Lapillonne (2011).

62 Paris Court of Appeal, 21 June and 6 July 1988, Gaz. Pal. 1988, 2, 700, Note Laurin.

63 Paris Court of Appeal, 21 June and 6 July 1988, Gaz. Pal. 1988, 2, 700, Note Laurin.

64 Koshevar (2013).

${ }^{65}$ Cumming and Freudenthal (2010).

${ }^{66}$ Mubangizi and Mbazira (2012).

67 Bartholomeusz (2005).

68 Murray (1994).

69 See Convention for the Protection of Human Rights and Fundamental Freedoms, Article $36(2)$.

${ }^{70}$ Levine (2011).

${ }^{71}$ For more information, see Statement of the Free Trade Commission on Non-Disputing Party Participation. 
Amicus curiae briefs recently monopolized the discussion concerning World Trade Organization dispute settlement proceedings. ${ }^{72}$ Amicus curiae briefs were submitted in the very first case brought before the WTO Panel and Appellate Body, the 'USA-Gasoline case'. However, it was the 'USA-Shrimp case'73 that opened the WTO door to amicus curiae - one of the most important cases on the admissibility of amicus curiae briefs in the WTO.$^{74}$ The Appellate Body held that it could consider amicus curiae briefs attached to a party's submission since the attachment of a brief or other material to either party's submission renders that material at least prima facie an integral part of that party's submission. ${ }^{75}$

\section{AMICUS CURIAE IN EAST EUROPEAN CIVIL LAW COUNTRIES: IS IT NEEDED IN CIVIL PROCEDURE?}

\subsection{Participants in the Case and their Interests}

The notion of amicus curiae is not known to the law of Ukraine and other post-socialist countries of Eastern Europe but there are similar in nature institutions of civil procedural law, which include, first of all, participation in the process of bodies and organizations in the execution of their powers (regarding the submission of conclusions). Lately, attempts have been made to introduce the amicus curiae institute, for example, in constitutional proceedings in Ukraine, ${ }^{76}$ as well as in Poland, ${ }^{77}$ which substantially actualizes interest in the amicus curiae institution in the civil process.

Amicus curiae from being active in the civil process since ancient times (see Part 2) and has undergone significant transformation. In the course of its evolution, it has initially absorbed the special features of the legal system of the country, in which legislation it had been adopted; has undergone certain changes during the development and reformation of the national legislation of the states, and has recently also been influenced by the harmonization and unification of the EU law and the general trend of globalization of law in the whole world.

The composition of the participants in the case is traditionally determined by defining their interest. Instead, the amicus curiae is usually characterized as a party without interest in the case e.g., H. A. Anderson insists that 'a myth persists that amicus curiae should be disinterested; that its only duty should be to assist the court - as the name 'friend of the court' implies - even though historically there was no such requirement' ${ }^{78}$ neutral participant or participant in a case from the court's side, e.g., S. Koshevar mentioned that amicus curiae as disinterested parties may offer input in court proceedings, while still allowing for a broad range of procedural and functional diversity. ${ }^{79}$ The neutrality of the conclusions of the amicus curiae is also a peculiar feature of the lack of interest of amicus curiae in the case. ${ }^{80}$

72 Mavroidis (2002).

73 Panel Report, United States-Import Prohibition of Certain Shrimp and Shrimp Products (1998).

74 Gao (2006).

75 For more information, see link 13.

76 See link 6.

77 Bernatt (2008)184-90.

78 Anderson (2016) 4.

79 Koshevar (2013) 1655.

80 Krislov (1963) 704. 
Ideas are circulating that 'friend of the court' must be distinguished from the witness, who certifies the existence of facts, and from the expert, who provides a technical opinion to the court, as their role is not to enlighten the court on a factual issue specific to the dispute at stake. ${ }^{81}$

If the amicus curiae is not a witness, not an expert and if the absence of any interest in the case is taken as a basis, the question will arise about the reasons for the relevance of its involvement in the case as a participant because the court is limited in the choice of its friends and the purposes with which it involves the case.

In reality, the expression of the interest of different participants in the case may be rather specific. The legal status and the complex of rights and obligations of various subjects of procedural relations depend on this. Therefore, usually persons who are not interested and not admitted to trial by a court may attend a court session in the courtroom, but this fact imposes certain rights and obligations on them, e.g., to adhere to the rules of conduct and to hear all that occurs in meeting to ensure the principle of openness and publicity.

The peculiarity of procedural relations is that in order to involve a particular person there must be certain ground and the procedure for assigning them to the appropriate status with a circle of all procedural rights and obligations adheres. A rather traditional approach to determining the general grounds for engaging in civil proceedings is the interest of individuals in L'intérêt est la mesure des actions and Pas d'intérêt, pas d'action. ${ }^{82}$ This approach is followed by most scholars, regardless of the legal system and traditions of doctrine. The best example is the Transnational Principles of Civil Procedure. ${ }^{83}$

At the same time, saying that the interest of different participants in the case is identical and essentially the same would be incorrect. First of all, a peculiar interest combines the parties to the dispute - it is significantly different from the interest of all other participants in the case, which, probably, would not have participated in this war, if they were not involved by material incentives. The last of the participants, the representatives of the parties, are usually guided by this interest - they represent the interests of the parties to the dispute, based on their existing professional knowledge of the law, but their interest lies in the plane of purely material gain. Therefore, their actions should always be treated accordingly. ${ }^{84}$

If the main reason for the participation of persons in the case is the interest of a person, it is worth determining what exactly it should consist of. It can be connected with the dispute, the reflection of the opposite interest of persons whose simultaneous satisfaction is not possible, or it is connected with the procedural interest, which is the fulfilment of the duty as a representative (lawyer) or a specialist (expert), a duty as of a citizen before a court (witness) or functions as an authority (court) but at the same time impartial and independent.

The parties are usually interested in the subject of the dispute and in resolving the case. In particular, the plaintiff is the initiator of the appeal to the court and the formulation of the initial claim to the defendant. ${ }^{85}$ It is the plaintiff who formulates the claim, as well as identifies the defendant, who in their opinion, violated the plaintiff's right, which became

81 Coslin, Lapillonne (2012) 14-15.

82 Roland, Boyer (1999) 304.

83 See ALI/UNIDROIT Transnational Principles of Civil Procedure (2005) last update 27 September 2016.

${ }^{84}$ An interesting point is the opinion expressed by A. Uzelac regarding the responsibility of the procedural representatives, see Uzelac (2017) 3-18.

85 See ALI/UNIDROIT Principles, 10.1-10.5. 
the basis for the dispute. The plaintiff is most interested in the process, since they are liable for the costs of legal expenses, and even if the defendant's active protection is denied, their claims may not be satisfied, e.g., if the court, on the basis of their evidence, was not convinced of their right or if they had the rights which they claim to be violated. ${ }^{86}$

The defendant is usually involved in the case at the discretion of the plaintiff, and their interest is related to the desire to defend their right. Accordingly, they have the right to file a counterclaim, which compensates for possible abuses of their right to sue the plaintiff, as well as to provide evidence against the claims made by the plaintiff. Accordingly, the defendant does not always have the duty to object to the claim actively - usually, they are guaranteed the right to object or to recognize the claim. ${ }^{87}$ The denial may be manifested in various forms, from active proof to a passive objection to a claim and the exclusion from participation in a court hearing, limited to obtaining judicial documents issued on the basis of the consideration.

As for other participants of the process, in particular, third parties, they are either in a status similar to the plaintiff's status or are interested in backing up the position of one of the parties, as well as representatives of parties and third parties acting on behalf of the parties and in their interests.

Participation of representatives of the parties cannot be based on their interest in the case. Representatives in the case represent professional public who provide special legal assistance, so their interest in the case may have a very negative effect on the process. Their interest is the support of one of the parties. Therefore, they cannot be regarded as impartial as a court, but they cannot be attributed to those directly interested in resolving the dispute. Accordingly, they are endowed with special procedural rights, which must be implemented in favor of justice in the case, not in favor of the parties. ${ }^{88}$

Therefore, all of the above persons are directly interested in the process and its outcome, unlike other subjects of civil procedural relations, in particular, the court.

The court's position in the process must first of all be impartial, so its interest in the case may only be related to the performance of its professional duties. ${ }^{89}$ Any interest in solving a case or supporting a position of the parties distorts the process of administering justice. Therefore, it would not be logical to call its participation in the case as an interest. On the contrary, it is worth to provide additional guarantees of the impartiality of the judge in the proceedings, in particular, in the process of proof. The adversarial process of legal proceedings was usually emphasized and offset by the rights of the parties to prove their rightness and circumstances of the case, but at the same time, the court had to maintain influence on the process. It is, after all, at best, an awkward notion that the judge has no business with the truth and it runs counter to a non-lawyer's idea of the role of a judge. ${ }^{90}$

The most interesting in this study is the status of witnesses who often participate in the case, in order to provide testimony about the circumstances known to them or facts. They are involved in the proceedings by the parties in the course of the proceedings but are held to be liable for knowingly false testimony, which is extremely rare in judicial practice.

86 See Ruiz Torija v. Spain (1994), Suominen v. Finland (2003) No 37801/97; Seryavin and others v. Ukraine (2010) No 4909/4.

87 See for example the Civil Procedure Code of Ukraine Articles 49 and 191, Articles 206, 207 of Civil Procedure Code of Poland.

88 Uzelac (2017) 15-17, and also ALI/UNIDROIT Principles, 11.5.

89 See ALI/UNIDROIT Principles, 1.1-1.5.

90 Jolowicz (2000) 391. 
At the same time, judges' specific assessment of witnesses` testimony can be encountered quite often in judgments of courts, when the court treats testimonies in a biased way.

What is the reason for the court to treat the testimony of the witness in this way and can the court summon a witness to clarify the circumstances of the case? Judges have the opportunity to find out not only the identity of the witness, their address, but may also specify the questions that will make it possible to determine the attitude of the witness to each of the parties, the subject of the dispute, the level of their awareness in the information that they provide the court. Witnesses have flaws as individuals and may deliberately be mistaken while giving their testimony, but unfortunately, they often retransmit the interpretation of events that is in line with the position of the party on whose side they are - there is even a notion of 'tainting' the witness. ${ }^{91}$

Judges are usually not endowed with the right to bring witnesses to a case, and even if they have the right to clarify the circumstances of the case, e.g., under the new Civil Procedure Code of Ukraine, they rarely use such opportunities. An evolutionary change in the approach of the court-to-party relationship between the active and passive poles to joint participation in the organisation of litigation, the case management, has opened new possibilities for the revision of rather traditional civil-engineering institutes, in particular, on the basic approaches to proof in the case.

The category of 'interest in the case' as the basis for involvement in the case is worthy of support. It is even possible to distinguish the dichotomy of this concept and the notion of 'impartiality of the court' since in this form, both institutions will become more complex. The interest of the parties and their opposing requirements is counterbalanced by the impartiality of the court, which accordingly carries out a professional duty to review and resolve the dispute in accordance with the established procedure. On the side of the parties are their representatives, as well as witnesses and experts involved, through which each party proves its rightness. Accordingly, the court, in the light of the implementation of the idea of the balance of influence of the court and parties on the organisation of consideration of the case, which also must be observed, may clarify the circumstances of the case if the parties fail to perform their duties. However, the court should use for those persons who are impartial in the consideration of the case, that is, representatives of the professional community, local authorities, unions and associations which, while participating in the case, can fulfil their powers of protection of the interests of their unions, and not express support for one of the parties. For the countries of Eastern Europe, especially post-socialist countries, this approach is an innovation that is just beginning to gain weight.

\subsection{Balance of Interests of the Parties and the Influence of the Court on the Process}

Case management in the civil process of the European countries is quite a new and interesting phenomenon ${ }^{92}$ borrowed from the results of the reformation of the civil justice system of Great Britain. ${ }^{93}$ At the same time, in the words of the authors of the reform itself, management is a new panacea for two of the most serious problems of modern civil justice: the length and the cost of the process. ${ }^{94}$ At the heart of this new approach lies a new view

91 See ALI/UNIDROIT Principles, 16.

92 Tulibacka et al. (2016).

93 Izarova, Silvestri (2018) 19-23.

94 Woolf Access to Justice, Interim Report, (1995); Access to Justice, Final Report, (1996). 
on the redistribution of the rights of the parties and the powers of the court, aimed at organizing the trial jointly and in cooperation. ${ }^{95}$

During the reform of the civil procedural legislation of Ukraine, changes were made and today in civil proceedings, the proof is carried out within the two-lane road, since the right to prove the circumstances of the case does not rest solely on the parties, which, in case of their unfairness, may also be seized by the court. According to Art 81 Part 7 of the Civil Procedure Code of Ukraine, the court cannot collect evidence relating to the subject matter of the dispute on its own initiative, except claiming evidence by a court in cases where it has doubts about the honest fulfilment of the parties' procedural rights or the performance of the duties regarding evidence, as well as other cases, provided by the Code. ${ }^{96}$

The court may, in accordance with the provisions of Article 103 of the Civil Procedure Code of Ukraine, designate an expert examination to determine the circumstances relevant to the case if special knowledge is required in a field other than law without which it is impossible to establish the relevant circumstances and if the parties (party) are not granted the relevant conclusions of the experts on the same issues or experts' conclusions raise the question about their correctness. ${ }^{97}$ At the same time, the issue from which the examination must be carried out, which is appointed by the court, is to be determined by the court, and the participants of the case have the right to propose the court questions, the explanation of which, in their opinion, requires an expert opinion.

Of course, when appointing such an examination, the court raises the question of choosing a particular expert or expert institution. In accordance with the law, the parties elect them by mutual consent, and if such agreement is not reached within the time limit set by the court, the court determines the expert or expert institution. However, it is not difficult to imagine that it is unlikely that agreement will be reached between the parties that have not given the appropriate conclusions, or these conclusions are questionable. In cases of appointment of such an expert or expert institution by a court, the question will arise regarding the payment for their conclusions.

Today the procedural legislation of Ukraine is the most progressive compared with the provisions of the law of other countries of Eastern Europe and Asia. In particular, the Civil Procedure Code of the Republic of Belarus contains the provision that the court has no right to clarify the circumstances of the case on its own initiative but may facilitate the demand for evidence (Article 20) and find it necessary to conduct an examination (Articles 179 and 221), ${ }^{98}$ which is the most difficult approach to the role of the court in the process of clarifying the circumstances of the case. Almost the same approach is in the Civil Procedure Code of Moldova, according to which the court plays a leading role in the process, by facilitating the parties to exercise their rights and deciding on the provision of evidence (Article 9), may invite the parties to provide additional evidence and prove the facts constituting the subject of evidence in order to ensure their authenticity (Article 118), on its initiative, the court may appoint an examination only in cases established by law (Article 185 and, for example, Article 305). ${ }^{99}$ On the contrary, the Civil Procedure Code of

95 About the judges, evidences and the case management after Woolf Reform please read more in Jolowicz (2000) 388-92. For the results of such a reform see details Sorabji (2014).

96 Civil Procedure Code of Ukraine (2018) link 4.

97 Civil Procedure Code of Ukraine (2018) link 4.

98 Civil Procedure Code of Republik Belarus (2018) link 1.

99 Civil Procedure Code of Republik Moldova ( 2018) link 3. 
Kazakhstan has the provision about the complete release of the court from collecting evidence by its initiative, but the court may assist the parties in claiming evidence (Article 15). The court may only propose to provide additional evidence (Article 73). At the same time, the court has the right to involve a specialist (77) in order to assist in the collection or study of evidence or appoint an examination (Article 82), ${ }^{100}$ not limiting to cases established by law.

In any case, the involvement of participants in the case on the initiative of the court can be considered as a special form of participation, a kind of amicus curiae, because their interest in the case is manifested only within the scope of its duty. At the same time, it is necessary to provide additional guarantees of the implementation of the principle of impartiality of the court and oblige the court to motivate its choices and to give the parties the right to object to the participation of such person in the case.

Swinging from an extremely active court to an extremely passive one in order to provide the parties with the opportunity to implement the principle of adversity did not fully produce results and did not ensure the effective administration of justice. Therefore, the search for a golden middle or a certain balance between the parties' influence on the process and the role of the court in it continue to occur in the countries of Eastern Europe, in particular in Ukraine. Providing the court with the right to claim evidence can be considered as a measure of prevention or protection against unfair behavior of the party or parties in the process, but it is worth defining the guarantees of the exercise of such a right. In particular, to consolidate the requirement to involve in participation to clarify the circumstances of persons with properties of the amicus curiae, who have no interest in the case or support of the parties. The court may involve them in providing information about the circumstances of a case that corresponds to the duties of such authority or person, and also imposes certain liability for the information provided. In this case, it is necessary to refer to the amicus curiae the conclusions of these bodies and persons who are called not to protect the rights of the concrete person but to adhere to the established rules that are assigned to a particular body or person or within their competence.

Traditionally, special participants took part in civil legal proceedings of Ukraine, whose interest was not limited to the specific requirements of the claim, but the obligations imposed on them by law. The Civil Procedure Code of Ukraine in the wording of Law No. 2875-12 of December 15, 1992, bodies of state administration, trade unions, enterprises, institutions, organizations and individuals protecting the rights of others (Articles 121-122), whose tasks was to implement the obligations imposed on their duties and for the protection of the rights of citizens and the interests of the state. ${ }^{101}$ These persons enjoyed fairly broad procedural rights in the process and were obliged to take part if the court found it necessary.

In the wording of the Civil Procedure Code of Ukraine of 2004, it was stated that in cases established by law, the Commissioner of the Verkhovna Rada of Ukraine for human rights, the public prosecutor, bodies of state authority, bodies of local self-government, individuals and legal entities were entitled not only to appeal to the court with applications for protection of rights, freedoms and interests of other persons, or state or public interests, but also to participate in these matters. State authorities and local self-government bodies could be involved in a case by participating in a case or take part in a case on their initiative to submit opinions for the exercise of their powers. Participation of these bodies in the civil

100 Civil Procedure Code of Republik Kazahstan (2018) link 3.

101 Civil Procedure Code of Ukraine (2018) link 4. 
procedure for the submission of opinions in the case was mandatory in cases established by law, or if the court finds it necessary. ${ }^{102}$ The last provision is stipulated in Part 6 of Art. 56 of the current CPC of Ukraine. ${ }^{103}$

The idea expressed by Helen A. Anderson in her 2016 work $^{104}$ on the classification of amicus curiae into several groups should be supported:

in light of their relationship to the court and the disputants, five major types emerge: These include lawyers appointed to argue a particular issue, groups or persons invited by the court to provide their perspective, those who advocate for one side of the dispute, those who support neither party, and those who just missed qualifying as interveners yet have a stake in the outcome.

This is a rather broad view on the amicus curiae phenomenon because its many varieties must be united by at least one common feature. In our opinion, the generalizing feature for the amicus curiae will be the basis for their involvement in the case - on the initiative of the court in order to clarify the circumstances of the case if unscrupulous execution by the party or parties of their duties for proving an impossibility to decide on the case. These include the experts involved at the request of the court, the bodies and individuals whom the court has drawn to give a conclusion in the case, the list of which cannot be detailed, enabling the court to act at its discretion, but guaranteeing the parties the right to object. ${ }^{105}$

Accordingly, it is worth considering them as a kind of amicus curiae institute, which gives it neutral information from the positions of the parties on the circumstances of the case under consideration. It is possible to consider the possibility of involving in the court process persons whose professional or special knowledge is necessary or may become useful to the court for the consideration of a case and the adoption of a decision in a case. These are associations of consumer protection, public and professional associations, such as notary chambers or lawyers' associations. Interest in their participation in the case will be determined not by the position of the parties, but by their professional activities, the exercise of their powers if this is related to the essence of the case under consideration. In this case, of course, there will be a question of paying the costs of the participation of these individuals in the process, since, in an established practice, the parties bear costs on their own, but expect to compensate them for winning their case. The presence of interest in the performance of their duties in case of involvement in the case of persons who may facilitate the administration of justice by their professional or special knowledge will provide grounds for the payment of such expenses on their own.

\section{CONCLUSIONS}

Every time period has its amicus curiae, and nominalism should be avoided. The practice is and must be different, including also nowadays across different jurisdictions, because the needs and everyday practicalities of the judiciary are different. Neither Roman law nor, in a later epoch, English law was willing to delimit amicus with a definition or specify situations

102 Civil Procedure Code of Ukraine (2018) link 4.

103 Civil Procedure Code of Ukraine (2018) link 4.

104 Anderson (2016) 1-2.

105 On the confirmation of this idea see ALI/UNIDROIT Principles, 13. 
in which a person may appear in that capacity. It was not then a procedural entitlement, but rather, a flexible instrument whose admissibility was to be decided by the court at its discretion. ${ }^{106}$ The function of protecting public interest seems to prevail these days. The role of amicus curiae is to share knowledge about broader aspects of the case, preventing negative effects of judgments which the court may, for whatever reason, be unable to foresee. The maxim iura novit curia should not be limited to a search for the right interpretation of legal regulations. The voice of the amicus curiae is not the cry of the mob driven by primitive emotions. This has been acknowledged in the case law and practice of the Polish Constitutional Court. In 2006, the Court ruled that the arguments presented by the amicus curiae allow a wider assessment of the problem, make rulings more socially acceptable, and promotes attitudes characteristic of a civic society. ${ }^{107}$

Nowadays, in an era of civic society, the judiciary is in the hands of lawyers. Though they may be, and surely are, distinguished experts on law, they may not know the full extent of the impact of their decisions. This is particularly important where judgment may refer to several similar cases, especially when a given problem is hotly debated in society. In the same way, as the non-lawyer judge in Roman law would take advice as to points of law and their interpretation, the modern-day judge needs to be informed of the legal and social consequences of a judgment they are about to pass. Talking about the 'here and now', in a time when politicians are testing the limits of legality, the opinions presented by nongovernmental organizations acting as amici curiae, such as the Helsinki Human Rights Foundation, may become today's equivalent of the Emperor intervening as the amicus iustitiae and stand as a testimony for generations to come.

Globalization has brought a peculiar diffusion of the law of various legal systems of the world, which is expressed in the borrowing of the most effective institutions. This process, quite traditional for Roman law, is much simplified today due to the wide possibilities of using comparative law techniques, joint research with the participation of representatives of different countries and systems. At the same time, this complicates the rule-making process, since it does not become complex in nature. With this in mind, borrowed institutions need to be coordinated with traditional institutions of national legislation. In the field of civil justice, there are a few such phenomena. Among the most tendentious are the group suits, simplified procedures, and also probably the amicus curiae, which is currently taking place in Europe, as is can be concluded from the third part of this study.

A generalizing sign of the amicus curiae in civil proceedings is the basis for their involvement - at the initiative of the court in order to clarify the case's circumstances in case of not fulfilling the duty of proving by the parties or a party. The complex nature of this institute will be obtained only in case of the implementation of the principle of a coherent organisation and consideration by the court and parties, or case management, which is not currently common in the countries of Eastern Europe. Accordingly, the court will be able to exercise its right to determine the case's circumstances in the case of unfair behavior of the parties in the framework of the principle of impartiality, without violating the fundamental principles of the administration of justice independently.

106 Krislov (1963) 695.

107 Cf. A judgement of the Republic of Poland's Constitutional Court of 16 January 2006, file ref. no. SK 30/05, OTK ZU no. 1/A/2006, item 2. 


\section{LITERATURE}

Anderson, Helen A., 'Frenemies of the Court: The Many Faces of Amicus Curiae' (2015) 49 University of Richmond Law Review 361-416.

Bartholomeusz, L., 'The Amicus Curiae Before International Courts and Tribunals' (2005) 5 NonState Actors \& Int'1 L. 209, 211-86.

Bernatt, Maciej, 'Opinia przyjaciela sądu (amicus curiae) jako pomocnicza instytucja prawna w orzecznictwie sądów polskich' in Ł. Bojarski (ed.), Sprawny sąd. Zbiór dobrych praktyk $(\mathrm{CH}$ Beck 2008) 184-90.

Boyer, Laurent and Roland, Henri, Adages du droit français (4 ${ }^{\text {th }}$ ed. LexisNexis 1999).

Collins, Paul M. Jr., 'Friends of the Court: Examining the Influence of Amicus Curiae Participation in U.S. Supreme Court' (2004) 4 Litigation Law and Society Review 807-32.

Coslin, Christelle, Lapillonne, Delphine, 'France and the Concept of Amicus Curiae: What Lies Ahead?' (2011) 4 Paris International Litigation Bulletin 14-15.

Cumming, George and Freudenthal Mirjam, Civil Procedure in EU Competition Cases Before the English And Dutch Courts (Kluwer Law International, 2010).

Franze, Anthony J. and Anderson, Reeves R., 'In Unusual Term, Big Year for Amicus Curiae at the Supreme Court' (2016) National Law Journal (September 21, 2016).

Gao, Henry S., 'Amicus Curiae in WTO Dispute Settlement: Theory and Practice' (2006) 1 Big Country, Small World 51 China Rights Forum 51-57.

Import Prohibition of Certain Shrimp and Shrimp Products, Appellate Body Report, United States WT/DS58/AB/R, adopted 6 November 1998, DSR 1998:VII, 2755.

Izarova, Iryna and Silvestri, Elisabetta, 'Case Management Principle in Civil Justice: A Comparative Study of the Legislation of Italy and Ukraine' (2018) 1(106) Bulletin of Taras Shevchenko National University of Kyiv 19-23.

Joint American Law Institute / UNIDROIT Working Group on Principles and Rules of Transnational Civil Procedure, ALI/UNIDROIT Principles of Transnational Civil Procedure. Appendix: rules of transnational civil procedure (A Reporter's Study), (2005). Last update 27 September 2016.

Jolowicz, John Anthony, On Civil Procedure (CUP 2000).

Kochevar, Steven, 'The Amici Curiae in Civil Law Jurisdictions' (2013) 122/6 The Yale Law Journal 1653-69.

Krislov, Samuel, ‘The Amicus Curiae Brief: From Friendship to Advocacy' (1963) 72/4 The Yale Law Journal 694-721.

Langbein, John H., 'The German Advantage in Civil Procedure' (1985) 4 University of Chicago Law Review 823-66.

Levine, Eugenia, 'Amicus Curiae in International Investment Arbitration: The Implications of an Increase in Third-Party Participation' (2011) 29 Berkeley J. Int'lLaw 200-24.

Lucas, Alison, 'Friends of the Court? The Ethics of Amicus Brief Writing in First Amendment Litigation' (1999) 26 Fordham Urb. L.J 1605-34.

Mavroidis, Petros Constantinos, 'Amicus Curiae Briefs Before The WTO: Much Ado About Nothing' (2001) 2 Jean Monnet Working Paper 1-18.

Mubangizi, John S. and Mbazira, Cristopher, 'Constructing the Amicus Curiae procedure in human rights litigation: What can Uganda learn from South Africa?' (2012) 16 Law, Democracy and Development 199-218.

Murray, Christina, 'Litigating in the Public Interest: Intervention and the Amicus Curiae' (1994) South African Journal on Human Rights.

Paris Court of Appeal, 21 June and 6 July 1988, Gaz. Pal. 1988, 2, 700, Note Laurin.

Re, Loretta, 'The Amicus Curiae Brief: Access to the Courts for Public Interest Associations' (1984) 14 Melbourne University Review, and Australian Quarterly 522-33.

Sorabji, John, English Civil Justice after the Woolf and Jackson Reforms: A Critical Analysis (CUP 2014).

Supreme Court of United Kingdom: The Supreme Court Rules (2009).

Tulibacka, Magdalena, Blomeyer, Roland, Sanz, Margarita, Common minimum standards of civil procedure (European Parliament EPRS PE 581.385, 2016). 
Uzelac, Alan, 'Towards European Rules of Civil Procedure: Rethinking Procedural Obligations' (2017) 58/1 Hungarian Journal of Legal Studies 3-18.

Woolf, Harry Kenneth, Access to Justice, Final Report (H.M. Stationery Office 1996).

Woolf, Harry Kenneth, Access to Justice, Interim Report (Lord Chancellor's Department, June 1995).

\section{LINKS}

1. Civil Procedure Code of Republik Belarus (2018) <http://kodeksy-by.com/grazhdanskij_ protsessualnyj_kodeks_rb/18.htm> accessed 29 July 2018.

2. Civil Procedure Code of Republik Kazahstan (2018) <https://online.zakon.kz/Document/?doc id=34329053\#pos=1503;-52> accessed 1 August 2018.

3. Civil Procedure Code of Republik Moldova (2018) <http://lex.justice.md/viewdoc.php?action=vie w\&view $=$ doc\&id $=286229 \&$ lang $=2>$ accessed 1 August 2018.

4. Civil Procedure Code of Ukraine (2018) <http://zakon3.rada.gov.ua/laws/show/1618-15> accessed 1 August 2018.

5. Convention for the Protection of Human Rights and Fundamental Freedoms (2018) $<$ https:// rm.coe.int/1680063765> accessed 29 July 2018.

6. Draft of the Law on amendments of Law of Ukraine (about the regulation of amicus curiae and briefs amicus and amicus ombud European Commission 'For the Democracy through Law' (Venetian Commission) in Constitutional Court of Ukraine and Ombudsmen in Parliament of Ukraine) $(2017)<\mathrm{http}: / /$ w1.c1.rada.gov.ua/pls/zweb2/webproc4_1?id=\&pf3511=61606> accessed 1 August 2018.

7. Federal Rule of Appellate Procedure (2018) $<$ https://www.law.cornell.edu/rules/frap $>$ accessed 30 July 2018.

8. Prefel S.A. v. Jae Ik Choi, 2002 (2010) <http://www.inta.org/Advocacy/Documents/INTAPrefel Choi.pdf $>$ accessed 1 August 2018.

9. Rules of The Supreme Court of the United States (2018) <https://www.law.cornell.edu/rules/ supct/rule_37> accessed 1 August 2018.

10. Statement of the Free Trade Commission on Non-Disputing Party Participation, NAFTA Free Trade Commission, 2003 (2012) <http://www.international.gc.ca/trade-agreements-accordscommerciaux/assets/pdfs/Nondisputing-en.pdf $>$ accessed 1 August 2018.

11. Cavallini, Cesare, 'Why Is the iura novit curia Principle Not Applied Yet in English Law?' (2017) 17 (3) Global Jurist, , Bocconi Legal Studies Research Paper No. 3175866 ( 2018) <https://papers. ssrn.com/sol3/papers.cfm?abstract id=3175866> accessed 25 September 2018.

12. Crema, Luigi, 'Tracking the origins and Testing the Fairness of the Instruments of Farness: Amici Curiae in International Litigation' (2012), 09/12 Jean Monnet Working Paper, NYU School of Law <https://jeanmonnetprogram.org/paper/tracking-the-origins-and-testing-the-fairness-of-theinstruments-of-fairness-amici-curiae-in-international-litigation/> accessed 25 September 2018.

13. US - Shrimp Case https://www.wto.org/english/tratop_e/dispu_e/cases_e/1pagesum_e/ds58sum e.pdf accessed 2 August 2018. 